\title{
Laboratory hybridization between the two clades of Liriomyza huidobrensis (Diptera: Agromyzidae)
}

\author{
Shun-Ichiro TaKano, ${ }^{* \dagger}{ }^{\dagger}$ Ren IwaIzumi, Yasuhiro NAKANISHI ${ }^{\ddagger}$ and Hitoshi Someya \\ Yokohama Plant Protection Station; Yokohama 231-0801, Japan
}

(Received 23 May 2007; Accepted 17 March 2008)

\begin{abstract}
We conducted mating experiments between two clades of the pea leafminer, Liriomyza huidobrensis, i.e., California Clade (CC) and South America Clade (SC). Development times from egg to pupa and egg to adult at $25^{\circ} \mathrm{C}$ of the two clades and the hybrid progeny were compared. In the interclade mating cross, adult hybrid progenies were obtained only from matings between CC females and SC males. The number of hybrid progeny was quite smaller than those from combinations of the same clade. Furthermore, no F2 progeny was obtained from matings between F1 hybrid progenies. $\mathrm{CC}$ progeny required more development times from egg to pupa and egg to adult at $25^{\circ} \mathrm{C}$ than $\mathrm{SC}$ and hybrid progeny. Our biological data indicated that the two clades of $L$. huidobrensis were different species, as indicated by their molecular characters in previous studies.
\end{abstract}

Key words: Cryptic species; clade; molecular character; hybrid; development time

\section{INTRODUCTION}

The pea leafminer, Liriomyza huidobrensis (Blanchard), is a highly polyphagous pest that causes serious crop damage in various areas of the world (Spencer, 1973; Suss, 1991; Weintraub and Horowitz, 1995; He et al., 2002). Host plants include Chenopodiaceae, Asteraceae, Cucurbitaceae, Leguminosae, Solanaceae and Apiaceae (Spencer, 1973). Larvae feed on plant tissues and leave the plant to pupate. Plants can be significantly damaged not only by larval feeding but also by oviposition and feeding punctures of adult females (Spencer, 1973).

In Japan, L. huidobrensis was first reported from Hokkaido Prefecture in 2001 (Iwasaki et al., 2004). The occurrence of this species was then reported in other areas such as Aomori (Shindo et al., 2005), Miyagi (Hayashi et al., 2005) and Yamaguchi (Takano et al., 2005) Prefectures. Vegetables, flowers and weed plants, including cucumber, Cucumis sativus L., China aster, Callistephus chinensis L. and livid amaranth, Amaranthus lividus L. var. as- cendens (Lois.) Thell., were attacked in Japan (Iwasaki et al., 2004; Hayashi et al., 2005; Shindo et al., 2005; Takano et al., 2005).

Recently, phylogenetic analysis using DNA sequence data revealed that there were two monophyletic groups within L. huidobrensis (Scheffer, 2000), i.e., the California Clade (CC) and the South America Clade (SC). Scheffer and Lewis (2001) resurrected the name L. langei Frick for CC and restricted the name L. huidobrensis to SC. In this article, however, we used CC and SC instead of resurrected or restricted names since that suggestion has not been universally accepted.

It has been reported that flies from California, Hawaii (Scheffer, 2000) and Mexico (Takano et al., 2005) belong to CC; those from Ecuador, Guatemala, Indonesia, Israel, Sri Lanka (Scheffer, 2000), Argentina, Colombia, Peru (Scheffer and Lewis, 2001), Canada, South Africa (Scheffer et al., 2001), China (He et al., 2002), Japan, Korea and Taiwan (Takano et al., 2005) are reported as SC. The wide diversity of DNA sequences between the two clades indicates that they are rather differ-

\footnotetext{
* To whom correspondence should be addressed at: E-mail: takanoshun@nifty.com

${ }^{\dagger}$ Present address: Ministry of Agriculture, Forestry and Fisheries, Chiyoda-ku, Tokyo 100-8950, Japan.

¥Present address: Tohoku Regional Agricultural Administration Office, Sendai 980-0014, Japan. DOI: $10.1303 /$ aez.2008.397
} 
ent at the species level (Scheffer and Lewis, 2001); however, fundamental biological information has not yet been elucidated. Takano et al. (2005) reported that CC specimens had many acrostichal setulae, longer female ovipositors and male aedeagal apodemes compared to SC. Also, the black parts of the anepisternum - the lateral sclerite of the thorax-were wider in $\mathrm{CC}$; however, those traits partly overlapped between the two clades. Due to the lack of data on biological information and separable morphological traits, the status of the two clades is still ambiguous.

Proper identification of species and basic biological studies are important for effective pest control since some morphologically similar pests have different biological traits (e.g. insecticide tolerance) providing information for the control (Parrella and Keil, 1984). In Liriomyza species, it is reported that L. sativae Blanchard harbors three distinct mitochondrial clades whose biological traits - such as host range or Wolbachia infections-seem to be different (Scheffer and Lewis, 2005). Morgan et al. (2000) showed that L. trifolii (Burgess) contains genetically distinct populations in California. Reitz and Trumble (2002) suggested that those populations could be reproductively isolated cryptic species. In Liriomyza species, it seems to be important to obtain biological information, taking into account the presence of clades or cryptic species; however, we have little information on the biological differences between the two clades of $L$. huidobrensis.

The aim of this work was to obtain basic biological information, such as reproductive isolation and development time, about the two clades of L. huidobrensis to decide their taxonomic status, which could be useful information for effective pest control. To reveal reproductive isolation, we conducted mating experiments between the two clades. Nuclear ribosomal DNA of the parent flies and their progeny was analyzed to confirm the results of the mating. We recorded their development times from egg to pupa and egg to adult.

\section{MATERIALS AND METHODS}

Colony establishment. Two clades of L. huidobrensis were maintained on garden peas, Pisum sativum L., for several generations under $16 \mathrm{~L}: 8 \mathrm{D}$ and $25 \pm 1{ }^{\circ} \mathrm{C}$ conditions.
Four peas were set in a rockwool pot $(5 \mathrm{~cm}$ $(\mathrm{W}) \times 5 \mathrm{~cm}(\mathrm{D}) \times 5 \mathrm{~cm}(\mathrm{H}))$ and placed in a plastic container for water supply. Three- to five-week-old pea seedlings were used for the flies. More than 50 adult flies were introduced into the cage $(30 \mathrm{~cm}$ $(\mathrm{W}) \times 28 \mathrm{~cm}(\mathrm{D}) \times 25 \mathrm{~cm}(\mathrm{H}))$ with enough rockwool pots containing more than 50 plants for several days. After sufficient feeding or oviposition punctures on plant leaves were observed, adult flies were removed from the cage to prevent excess puncture causing plant death.

SC was introduced from infested sugar beet, Beta vulgaris L. collected in October 2004 in the Iburi Subprefecture of Hokkaido Prefecture, komatsuna, Brassica rapa L. nothovar. and qinggeng-cai, Brassica rapa L. var. chinensis leaves collected in October 2005 in the same region. CC was introduced from infested lettuce, Lactuca sativa L. which was imported from California, USA, and intercepted at Narita International Airport in July 2005. CC had been reared with permission from the Ministry of Agriculture, Forestry and Fisheries, Japan. The clades of specimens obtained from the two areas were confirmed by the PCRRFLP method (Scheffer et al., 2001) before the experiment.

Mating experiments. Mating experiments were conducted under the same conditions and facilities as colony establishment. A group of four virgin female and four 1-3-day-old male flies was introduced into the plastic cage $(30 \mathrm{~cm}(\mathrm{~W}) \times 28 \mathrm{~cm}$ (D) $\times 25 \mathrm{~cm}(\mathrm{H}))$ for $24 \mathrm{~h}$ with four 3-5-week-old pea seedlings in a rockwool pot $(5 \mathrm{~cm}(\mathrm{~W}) \times 5 \mathrm{~cm}$ (D) $\times 5 \mathrm{~cm}(\mathrm{H}))$ within a plastic cup $(10 \mathrm{~cm}$ diameter at the top, $4.5 \mathrm{~cm}$ high) as a water supply. After $24 \mathrm{~h}$ exposure, the plants were replaced and this was repeated each 5-6 days for each group. Each treatment has four replications (Table 1). Each exposed plant cup was placed in an individual nylon net $(40 \mathrm{~cm}(\mathrm{~W}) \times 70 \mathrm{~cm}(\mathrm{D}), 0.25 \mathrm{~mm}$ mesh size). The presence of larval mines were observed and pupae emerged from their mines were collected from inside the net and placed individually into glass vials ( $1 \mathrm{~cm}$ in diameter, $5 \mathrm{~cm}$ high) every day in order to record the development times from egg to pupa. The development periods from egg to adult and the sex of adult flies were recorded every day. When progenies were obtained from a combination of different clades, all progenies were introduced into the same cage with four pea seedlings 
until they died to check their fertility. The plants were prepared in the same manner as in the mating experiments described above. The presence of larval mines was observed every day.

DNA analyses. For DNA analysis, specimens from the laboratory colony of both clades and progenies obtained from combination of different clades were preserved in $99.5 \%$ ethanol and stored at $-20^{\circ} \mathrm{C}$ until DNA extraction. DNA was extracted from six legs detached from each specimen. The legs were homogenized in a $1.5 \mathrm{ml}$ microfuge tube containing $80 \mu \mathrm{l}$ of phosphate-buffered saline. Subsequent DNA extraction followed the tissue protocol of the QIAamp DNA Mini Kit (QIAGEN K.K.). The extraction was stored at $-20^{\circ} \mathrm{C}$ until used in polymerase chain reaction (PCR) as a DNA template. PCR primers, 5'-ACCGCCCGTCGCTACTACCGAT-3' (Muraji, unpublished) and 5'TGTTCATGTGTCCTGCAGTTCACA-3' (Muraji et al., 2004) were used to amplify the ITS1 and flanking regions of nuclear ribosomal DNA. PCRs were conducted with $3.0 \mu \mathrm{l}$ of each DNA template, $10 \times$ PCR buffer, $2.5 \mathrm{~mm} \mathrm{MgCl}_{2}, 2 \mathrm{mM}$ of each dNTP, $0.5 \mu \mathrm{M}$ of each primer, and 5 units of AmpliTaq Gold ${ }^{\circledR}$ DNA Polymerase (Applied Biosystems) in a $40 \mu \mathrm{l}$ total reaction volume. The conditions for PCR amplification using a Program temp control system PC818 (ASTEC Co., Ltd.) were as follows: an initial denaturing step at $95^{\circ} \mathrm{C}$ for $10 \mathrm{~min} ; 35$ cycles of $94^{\circ} \mathrm{C}$ for $45 \mathrm{~s}, 47^{\circ} \mathrm{C}$ for $45 \mathrm{~s}, 72^{\circ} \mathrm{C}$ for $1 \mathrm{~min} 30 \mathrm{~s}$; and a final extension step of $72^{\circ} \mathrm{C}$ for $7 \mathrm{~min}$. Amplified rDNA fragments were purified using the QIAquick PCR Clean-Up Kit (QIAGEN K.K.), and sequenced using an ABI 3130 Genetic Analyzer (Applied Biosystems) with the BigDye Terminator v3.1 Cycle Sequencing Kit (Applied Biosystems). Sequence data were aligned using the
ClustalX program (Thompson et al., 1994), and then compared with the rDNA sequence of $L$. huidobrensis including a partial sequence of the $18 \mathrm{~S}$ ribosomal RNA gene, complete sequence of internal transcribed spacer 1, and partial sequence of the 5.8S ribosomal RNA gene (Accession AY323208). Amplified PCR products were digested by each of two restriction enzymes, DraI and AseI (Nippon Gene Co., Ltd.) in separate reactions. The resulting DNA was electrophoresed on a $2.0 \%$ (DraI) or 3.0\% (AseI) Metaphore agarose gel (BioWhittaker Molecular Applications), and then visualized by staining with ethidium bromide.

\section{RESULTS AND DISCUSSION}

Feeding and/or oviposition punctures on pea leaves were found in all mating crosses. In the interclade mating cross, adult progenies were obtained only from that between CC females and SC males. No larval mines were observed from plants exposed to CC males and SC females. Mean numbers of pupal and adult progenies produced by each female after interclade copulation were an order of magnitude smaller than the numbers produced after intraclade copulation (Table 1). Three male and five female progenies were obtained in two of the four replicates of the mating cross between $\mathrm{CC}$ females and SC males. Two mating experiments between $\mathrm{F} 1$ progenies were then conducted, and no larval mines of F2 progeny were observed in either replication.

The final alignment of $175 \mathrm{bp}$ rDNA sequence data was obtained from twelve $L$. huidobrensis specimens (position 1-62="18S ribosomal RNA", 63-175="ITS1"). The 136 bp (position 39-175) sequences of the SC were completely identical to

Table 1. Results of cross tests of the two clades of $L$. huidobrensis on pea seedlings $\left(25^{\circ} \mathrm{C} 16 \mathrm{~L}: 8 \mathrm{D}\right)$

\begin{tabular}{|c|c|c|c|c|c|c|c|c|c|c|c|c|c|}
\hline \multirow{2}{*}{\multicolumn{2}{|c|}{ Combination $^{\mathrm{a}}$}} & \multicolumn{12}{|c|}{ Total no. of emerged pupae and adults in each replication } \\
\hline & & \multicolumn{3}{|c|}{ First } & \multicolumn{3}{|c|}{ Second } & \multicolumn{3}{|c|}{ Third } & \multicolumn{3}{|c|}{ Fourth } \\
\hline Male & Female & Pupae & Male & Female & Pupae & Male & Female & Pupae & Male & Female & Pupae & Male & Female \\
\hline $\mathrm{SC}$ & $\mathrm{SC}$ & 52 & 14 & 11 & 225 & 58 & 46 & - & - & - & - & - & - \\
\hline $\mathrm{CC}$ & $\mathrm{CC}$ & 118 & 18 & 18 & 146 & 26 & 27 & - & - & - & - & - & - \\
\hline $\mathrm{SC}$ & $\mathrm{CC}$ & 4 & 0 & 0 & 10 & 3 & 5 & 0 & 0 & 0 & 8 & 3 & 5 \\
\hline $\mathrm{CC}$ & $\mathrm{SC}$ & 0 & 0 & 0 & 0 & 0 & 0 & 0 & 0 & 0 & 0 & 0 & 0 \\
\hline
\end{tabular}

\footnotetext{
${ }^{a}$ SC, South America Clade; CC, California Clade.
} 
the sequences of L. huidobrensis (AY323208) except for two gaps. There were, however, some differences between the sequences of SC and CC. Some bands were shared between paternal clade (SC) and progeny from the combination of $\mathrm{CC}$ female and SC male in the digested patterns of ITS1 and the flanking regions of rDNA by DraI and AseI, respectively (Fig. 1). The results of DNA analysis indicate that progeny obtained in the mating experiment were not reproduced parthenogenetically.

With the present data, it is not possible to determine what induced the difference in reproductive success between interclade and intraclade copulation. The number of eggs laid, hatchability or the

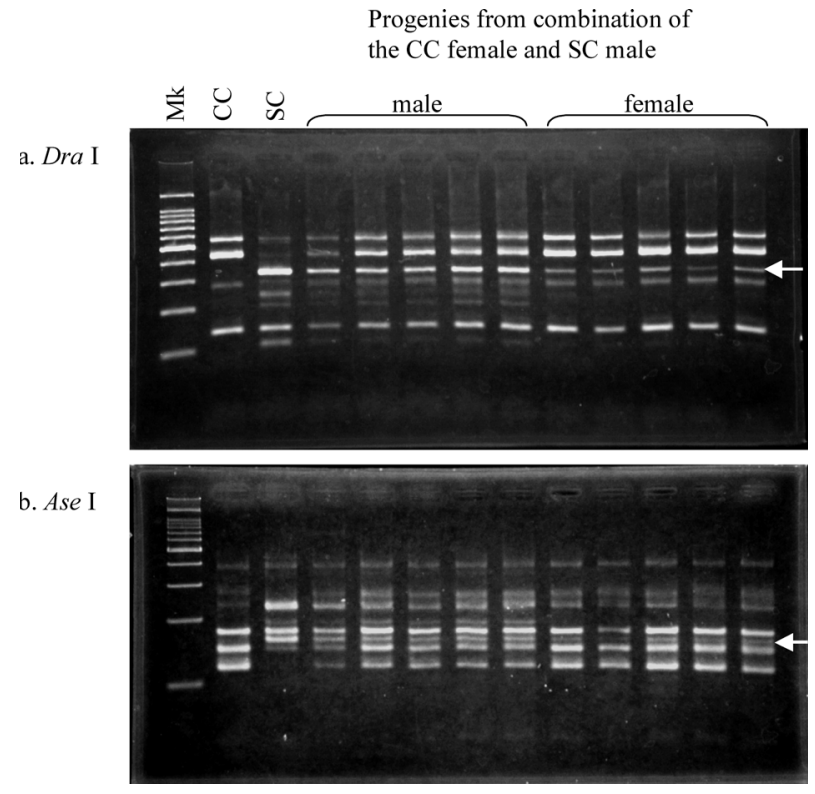

Fig. 1. Restriction enzyme digested patterns of ITS1 and the flanking regions of rDNA (a: DraI, 2.0\% agarose gel. b: Ase I 3.0\% agarose gel). Mk: DNA size marker (100 bp ladder), CC: California Clade (maternal), SC: South America Clade (paternal). Pointed arrows indicate bands shared between SC and hybrid progenies. mortality of larvae may cause a difference in reproductive success.

Taking into account reproductive success, it seems that hybrid progeny hardly occur under natural conditions, even if two clades occur sympatrically. Furthermore, no F2 adult progeny was obtained from matings between $\mathrm{F} 1$ hybrid progenies. The results of mating experiments between two clades of $L$. huidobrensis indicate that they are actually different species.

$\mathrm{CC}$ progeny required more development times from egg to pupa and egg to adult at $25^{\circ} \mathrm{C}$ than $\mathrm{SC}$ and hybrid progeny (Scheffe's test, $p<0.05$ ). In hybrid progeny, the development times from egg to pupa were not significantly different from those of SC progeny (Scheffe's test, $p>0.05$ ), but development times from egg to adult were longer than those of SC progeny (Scheffe's test, $p<0.05$ ) (Table 2).

So far, there has been some research on the development time of L. huidobrensis (Parrella and Bethke, 1984; He et al., 2000; Zhou et al., 2000; Lanzoni et al., 2002; Iwasaki et al., 2004). Taking into account the distribution of SC (Scheffer et al., 2001; He et al., 2002), it is estimated that most data pertaining to the development times in the experiment mentioned above were revealed for SC, and the development times of SC seem to vary with the host plants. Information on CC is limited; however, it is assumed that SC can develop slightly faster than CC (Table 3). Our results also indicate that $\mathrm{SC}$ developed slightly faster at $25^{\circ} \mathrm{C}$ than $\mathrm{CC}$. It can be recognized that not only molecular characters but also biological traits are different between the two clades.

Our data indicate that the two clades of L. huidobrensis should actually be different species, as indicated by their molecular characters in previous studies (Scheffer, 2000; Scheffer and Lewis, 2001).

Table 2. Development periods of $L$. huidobrensis on pea seedlings at $25 \pm 1^{\circ} \mathrm{C}$

\begin{tabular}{|c|c|c|c|c|c|}
\hline \multicolumn{2}{|c|}{ Combination $^{\mathrm{a}}$} & \multicolumn{4}{|c|}{ Development period in days (Mean $\pm \mathrm{SD}^{\mathrm{b}}$ ) } \\
\hline Male & Female & $n$ & From egg to pupa & $n$ & From egg to adult \\
\hline $\mathrm{SC}$ & $\mathrm{SC}$ & 63 & $7.95 \pm 0.49 \mathrm{a}$ & 86 & $17.23 \pm 0.71 \mathrm{a}$ \\
\hline $\mathrm{CC}$ & $\mathrm{CC}$ & 66 & $9.11 \pm 0.66 b$ & 94 & $18.80 \pm 0.85 b$ \\
\hline $\mathrm{SC}$ & $\mathrm{CC}$ & 7 & $8.14 \pm 0.38 \mathrm{a}$ & 16 & $17.88 \pm 0.96 \mathrm{c}$ \\
\hline
\end{tabular}

\footnotetext{
${ }^{\text {a }}$ See Table 1.

${ }^{\mathrm{b}}$ Means in a column followed by the italic same letter are not significantly different $(p>0.05)$, by Scheffe's test.
} 
Table 3. Comparison of development periods of L. huidobrensis on various hosts at different temperature

\begin{tabular}{|c|c|c|c|}
\hline \multirow{2}{*}{$\begin{array}{c}\text { Clade } \\
(\text { estimated })^{\mathrm{a}}\end{array}$} & \multirow{2}{*}{ Host plant } & \multicolumn{2}{|c|}{ Mean development periods (days) } \\
\hline & & $25.0^{\circ} \mathrm{C}$ & $26.7^{\circ} \mathrm{C}$ \\
\hline \multirow[t]{6}{*}{$\mathrm{SC}$} & Phaseolus vulgaris L. & $15.3^{\mathrm{b}}$ & \\
\hline & Phaseolus vulgaris L. & $16.1^{\mathrm{c}}$ & \\
\hline & Vicia faba L. & $16.3^{\mathrm{d}}$ & \\
\hline & Lactuca sativa $\mathrm{L}$. & $16.5^{\mathrm{e}}$ & $14.4^{\mathrm{e}}$ \\
\hline & Pisum sativum L. & $17.2^{\mathrm{f}}$ & \\
\hline & Vigna unguiculata (L.) Walp. subsp. unguiculata & $17.3^{\mathrm{g}}$ & \\
\hline \multirow[t]{3}{*}{$\mathrm{CC}$} & Pisum sativum L. & $18.8^{\mathrm{f}}$ & \\
\hline & & & $15.3(\text { male })^{\mathrm{h}}$ \\
\hline & & & $15.4(\text { female })^{\mathrm{h}}$ \\
\hline
\end{tabular}

${ }^{a}$ See Table 1.

${ }^{\mathrm{b}}$ Iwasaki et al. (2004), ${ }^{\mathrm{c}}$ Lanzoni et al. (2002), ${ }^{\mathrm{d}} \mathrm{He}$ et al. (2000), ${ }^{\mathrm{e}}$ calculated from Head et al. (2002), ${ }^{\mathrm{f}}$ present examination,

${ }^{\mathrm{g}}$ Zhou et al. (2000), ${ }^{\mathrm{h}}$ Parrella and Bethke (1984).

Further investigation of the basic biology of the two clades and hybrid progenies such as analysis of their mating behavior, number of eggs laid, hatchability or the mortality of larvae will provide more information on the taxonomic status of those two species. For effective control, it is important to obtain more biological information on the two species, such as host range and insecticide susceptibility and to identify them appropriately.

\section{ACKNOWLEDGEMENTS}

We thank the staff of the Research Division of Yokohama Plant Protection Station, Mr. Akeo Iwasaki, and anonymous reviewers for providing helpful comments on the manuscript. We also thank Dr. Masahiko Muraji who provided information on the primer.

\section{REFERENCES}

Hayashi, K., M. Kondou, S. Ando, T. Masuda and S. Tokumaru (2005) Occurrences and overwintering of Liriomyza huidobrensis (Blanchard) (Diptera: Agromyzidae) in Miyagi Prefecture. Ann. Rept. Plant Prot. North Japan 56: 149-151 (in Japanese).

He, C., Y. Tao and L. Wang (2000) Studies on the developmental duration and effective accumulated temperature of Liriomyza huidobrensis on broad bean. J. Yunnan Agric. Univ. 15: 330-332.

He, L., Y. Zhang, N. Xiao, J. Wei and R. Kuang (2002) Liriomyza huidobrensis in Yunnan, China: current distribution and genetic structure of recently established population. Entomol. Exp. Appl. 102: 213-219.

Head, J., K. F. A. Walters and S. Langton (2002) Utilisation of morphological features in life table studies of Liriomyza huidobrensis (Dipt., Agromyzidae) developing in lettuce. J. Appl. Entomol. 126: 349-354.
Iwasaki, A., R. Iwaizumi and S. I. Takano (2004) A newly recorded pest, Liriomyza huidobrensis (Blanchard) in Japan. Plant Prot. Bull. 58: 13-19 (in Japanese).

Lanzoni, A., G. G. Bazzocchi, G. Burgio and M. R. Fiacconi (2002) Comparative life history of Liriomyza trifolii and Liriomyza huidobrensis (Diptera: Agromizidae) on beans: effect of temperature on development. Environ. Entomol. 31: 797-803.

Morgan, D. J. W., S. R. Reitz, P. W. Atkinson and J. T. Trumble (2000) The resolution of California populations of Liriomyza huidobrensis and Liriomyza trifolii (Diptera: Agromyzidae) using PCR. Heredity 85: 53-61.

Muraji, M., K. Kawasaki, T. Shimizu and T. Noda (2004) Discrimination among Japanese species of the Orius flower bugs (Heteroptera: Anthocoridae) based on PCRRFLP of the nuclear and mitochondrial DNAs. Jap. Agric. Res. Quar. 38: 91-95.

Parrella, M. P. and J. A. Bethke (1984) Biological studies of Liriomyza huidobrensis (Diptera: Agromyzidae) on chrysanthemum, aster, and pea. J. Econ. Entomol. 77: 342-345.

Parrella, M. P. and C. B. Keil (1984) Insect pest management: the lesson of Liriomyza. Bull. Entomol. Soc. Am. 30: $22-25$.

Reitz, S. R. and J. T. Trumble (2002) Interspecific and intraspecific differences in two Liriomyza leafminer species in California. Entomol. Exp. Appl. 102: 101-113.

Scheffer, S. J. (2000) Molecular evidence of cryptic species within the Liriomyza huidobrensis (Diptera: Agromyzidae). J. Econ. Entomol. 93: 1146-1151.

Scheffer, S. J. and M. L. Lewis (2001) Two nuclear genes confirm mitochondrial evidence of cryptic species within Liriomyza huidobrensis (Diptera: Agromyzidae). Ann. Entomol. Soc. Am. 94: 648-653.

Scheffer, S. J. and M. L. Lewis (2005) Mitochondrial phylogeography of vegetable pest Liriomyza sativae (Diptera: Agromyzidae): divergent clades and invasive populations. Ann. Entomol. Soc. Am. 98: 181-186. 
Scheffer, S. J., A. Wijesekara, D. Visser and R. H. Hallett (2001) Polymerase chain reaction-restriction fragmentlength polymorphism method to distinguish Liriomyza huidobrensis from L. langei (Diptera: Agromyzidae) applied to three recent leafminer invasions. J. Econ. Entomol. 94: 1177-1182.

Shindo, J., M. Kinota, S. Inokuchi, Y. Kimura and T. Fujimura (2005) Occurrence of pea leafminer, Liriomyza huidobrensis (Blanchard) (Diptera: Agromyzidae), in Aomori Prefecture. Ann. Rept. Plant Prot. North Japan 56: 145-148 (in Japanese with English summary).

Spencer, K. A. (1973) Agromyzidae (Diptera) of Economic Importance. Dr. W. Junk B. V., The Hague. 418 pp.

Suss, L. (1991) First record in Italy of Liriomyza huidobrensis (Blanchard) (Diptera, Agromyzidae). Boll. Zool. Agr. Bachic. 23: 197-202.

Takano, S. I., R. Iwaizumi, Y. Nakanishi, H. Someya and A.
Iwasaki (2005) Genetic differentiation and morphological comparison between two clades of Liriomyza huidobrensis (Blanchard) (Diptera: Agromyzidae). Res. Bull. Pl. Prot. Japan 41: 43-46 (in Japanese with English summary).

Thompson, J. D., D. G. Higgins and T. J. Gibson (1994) CLUSTAL W: improving the sensitivity of progressive multiple sequence alignment through sequence weighting, positions-specific gap penalties and weight matrix choice. Nucleic Acids Res. 22: 4673-4680.

Weintraub, P. G. and A. R. Horowitz (1995) The newest leafminer pest in Israel, Liriomyza huidobrensis. Phytoparasitica 23: 177-184.

Zhou, Y., Z. Zhao, X. Deng and S. Wu (2000) Effect of temperature on the population of Liriomyza huidobrensis (Blanchard). J. Nanjing Agric. Univ. 23: 33-36. 